Chirurgia (2018) 113: 116-122

No. 1, January - February

Copyright@ Celsius

http://dx.doi.org/10.21614/chirurgia.113.1.116

\title{
Distant Oncologic Outcome of Patients with Locally Advanced Unresectable and Metastatic Esophageal Cancer after Multimodality Treatment
}

\author{
Rodica Anghel ${ }^{1,2}$, Silviu Constantinoi ${ }^{2,3}$, Xenia Bacinschi ${ }^{1,2}$, Laurentia Gales ${ }^{1,2}$, Radu-Valeriu Toma ${ }^{1,2}$, Oana Trifanescu ${ }^{1,2}$ \\ 'Prof. Dr. Al. Trestioreanu Institute of Oncology Bucharest, Romania \\ ${ }^{2}$ Carol Davila University of Medicine and Pharmacy, Bucharest, Romania \\ ${ }^{3}$ General and Esophageal Surgery Clinic, Center of Excellence in Esophageal Surgery, Sf. Maria Clinical Hospital, Bucharest, Romania
}

Corresponding author:

Oana Trifanescu, MD

Prof. Dr. Al. Trestioreanu Institute of Oncology Bucharest, Romania

E-mail: oanatrifanescugab@yahoo.com

\section{Rezumat}

Evolutia pe termen lung a pacientilor cu cancer esofagian local avansat și metastatic după tratamentul multimodal

Introducere: Terapia multidmodală este utilizată ca tratament de referință în cazul cancerului esofagian şi al cancerului de joncțiune eso-gastrică, la nivel mondial, dar nu există un consens unanim. Metode: Au fost revizuite retrospectiv dosarele medicale a 132 de pacienți diagnosticați cu cancer esofagian local avansat, neoperabil şi metastatic, internați în centrul nostru în perioada 2010-2015. Tratamentul multimodal a constat în chimioterapie, radioterapie sau chimio-radioterapie şi chirurgie şi a fost planificat în funcție de extinderea tumorii şi statusul de performanță a pacientului.

Rezultate: În urma examenului histopatologic, 77\% dintre pacienți au fost diagnosticați cu carcinom scuamos şi $23 \%$ au fost diagnosticați cu adenocarcinom. Dintre aceştia, 16,6 \% (22 de pacienți) au fost diagnosticați în stadiul IV, 19,7 \% (26 de pacienți) au efectuat chimioradioterapie concomitentă, iar 68,9\% (91 de pacienți) au urmat chimioterapie în timp ce $62,9 \%$ (83 pacienți) au urmat radioterapie. După tratamentul combinat, intervenția chirurgicală cu intenție radicală a fost posibilă la 15,9 \% (21 pacienți). După o urmărire de 17,3 luni, mediana supraviețuirii globale (OS) a populației a fost de 12 luni, cu o rată de supraviețuire la un an şi la 2 ani de $49,2 \%$ şi 17,4\%. La pacienții metastazați, supraviețuirea mediană globală a fost de 10 luni. Pacienții care au fost convertiți la operabilitate au avut o mediană a supraviețuirii OS de 20 de luni, comparativ cu 10 luni, la pacienții care nu au urmat intervenții chirurgicale 
$(p=0,002)$. Chimio-radioterapia a fost superioară în ceea ce priveşte supraviețuirea globală în comparație cu chimioterapia sau radioterapia administrată secvențial (17 luni vs. 10 luni, $p=0,013$ ). Concluzii: Tratamentul multimodal în cancerele esofagiane avansate la nivel local (radio-chimioterapie concomitentă, urmată de chirurgie) poate fi considerat superior fiecărei metode administrate ca mono-terapie, iar radioterapia şi chimioterapia pot determina ca anumite tumori esofagiene avansate la nivel local să fie rezecabile.

Cuvinte cheie: cancerul esofagian, radioterapia, chimioterapia, chirurgia, tratamentul multimodal

\begin{abstract}
Background: Combined modality therapy has been employed for the treatment of choice for locally advanced esophageal and eso-gastric junction cancers all around the globe but a unanimous consensus is missing.

Methods: Medical files of 132 patients with confirmed locally advanced un-resectable, and metastatic esophageal cancer who presented to our center between 2010-2015 were retrospectively reviewed. Multimodality treatment consisting of chemo-radiotherapy or chemotherapy or radiotherapy alone and surgery in patients who convert to operability was planned according to tumor extend and performance status of the patient.

Results: Seventy seven percent of the patient presented with squamous carcinoma and $23 \%$ were adenocarcinoma. At the diagnosis 22 patients (16.6\%) were stage IV. Concurrent chemoradiotherapy was administered in 26 patients (19.7\%), chemotherapy in 91 patients $(68.9 \%$ ), radiotherapy in 83 patients $(62.9 \%)$. After combined treatment, surgery with radical intent was possible in 21 patients (15.9\%). After a follow up of 17.3 months, overall survival (OS) was 12 months, with one and two-year survival rate of $49.2 \%$ and $17.4 \%$. In metastatic patients OS was 10 months. Patients who were converted to operability had a OS of 20 months vs. 10 months in patients who doesn't undergo surgery $(\mathrm{p}=0.002)$. Chemo-radiotherapy was superior in terms of OS compare with chemotherapy or radiotherapy administered sequential ( 17 vs. 10 months, $p=0.013$ ).

Conclusions: Multimodality treatment in locally advanced esophageal cancers (concurrent radiochemotherapy followed by surgery) can be considered superior to each method as single therapy and radiotherapy and chemotherapy can make certain locally advanced esophageal tumors resectable.
\end{abstract}

Key words: esophageal cancer, radiotherapy, chemotherapy, surgery, multimodal treatment

\section{Intoduction}

Esophageal cancer is the eight most common cancer worldwide and the sixth most cause of death from cancer (1). Most cases occur in less developed countries and in Europe is the $19^{\text {th }}$ most common cancer. Differences in the incidence of the esophageal cancer around the globe can be linked to the differences in exposure to risk factors (2). The most common histopathological type is squamous cell carcinoma, but the mortality rates in adenocarcinomas are higher in some regions in Europe. The early diagnosis with a good management of the disease is of utmost importance in order to ensure treatment effectiveness (3). Despite the advancements in treatment and diagnostics, the 5-year survival remains very poor (15-20\%) (4). Esophageal cancer is recognized to be aggressive and has complex lymphogenichematologic pathways, resulting into distant metastases that cause the cancer-related deaths (5). Combined modality therapy has been employed for the treatment of choice for 
locally advanced esophageal and esophageal gastric junction (EGJ) cancers all around the globe but a unanimous consensus is missing. The aim of the study was to evaluate the results of multimodality treatment and the distant outcome of patients with locally advanced unresectable and metastatic esophageal cancer.

\section{Patients and Methods}

Medical files of 132 consecutive patients with confirmed locally advanced un-resectable, unoperable and metastatic esophageal cancer who presented to our centre between 20102015 were retrospectively reviewed.

Inclusion criteria consisted all histopathological confirmed squamous or adenocarcinoma of the oesophagus with locally advanced or metastatic un-resectable disease, (stage III and IV) ECOG 0-2, with normal hematologic, liver and renal function, fit and willing to undergo multimodality treatment.

Demographic date of the patients such as age, gender, performance status was obtained. The analysed variables were oncologic stage, histopathological type, grade of cellular differentiation, the therapeutic sequences, survival time, progression free survival time.

Multimodality treatment consisting of chemo-radiotherapy or chemotherapy or radiotherapy alone was planned according to tumour extend and performance status of the patient. Radiotherapy was administered a in a 3D conformal external beam manner to a total dose of 45-50.4 Gy. Chemoradiotherapy consisted in administration of radiotherapy concurrent with Cisplatin $75 \mathrm{mg} / \mathrm{m}^{2}$ Day $1+5^{-}$ fluorouracil (5-FU) $750-1000 \mathrm{mg} / \mathrm{m}^{2}$ Days $1-4$ $\mathrm{q} 4 \mathrm{w}$ or Paclitaxel $50 \mathrm{mg} / \mathrm{m}^{2} \mathrm{IV}+$ Carboplatin AUC 2 IV Day $1 \mathrm{q} 1 \mathrm{w}$ or Cisplatin $40 \mathrm{mg} / \mathrm{m}^{2}$ q1w. Chemotherapy used consisted in Cisplatin $75 \mathrm{mg} / \mathrm{m}^{2}$ Day 1 + 5-FU 750-1000 mg/ $\mathrm{m}^{2}$ Days 1-4 q4w or Paclitaxel $175 \mathrm{mg} / \mathrm{m}^{2}+$ Cisplatin $75 \mathrm{mg} / \mathrm{m}^{2}$ or Carboplatin AUC $5 \mathrm{q} 3 \mathrm{w}$, or for adenocarcinoma Docetaxel $75 \mathrm{mg} / \mathrm{m}^{2} \mathrm{IV}$ Day 1+Cisplatin $75 \mathrm{mg} / \mathrm{m}^{2}$ IV Day $1+5$-FU $750 \mathrm{mg} / \mathrm{m}^{2}$ IV Day 1-5 q4w or Epirubicin 50 $\mathrm{mg} / \mathrm{m}^{2} \mathrm{IV}$ day $1+$ Oxaliplatin $130 \mathrm{mg} / \mathrm{m}^{2} \mathrm{IV}$ day 1 +Capecitabine $625 \mathrm{mg} / \mathrm{m}^{2}$ BID Day 1-21.
All eligible patients were included in the statistical calculations. The statistical analysis was performed using SPSS 17.0 for Windows. The following endpoints were analysed: progression free survival PFS, defined as the interval between the date of diagnosis and first progression of the disease or death by any cause; and overall survival OS, defined as the interval from date of diagnosis until the date of death by any cause. Survival data were calculated using the Kaplan-Meier method.

\section{Results}

Demographic characteristics showed a higher incidence in men $(78 \%)$ and median age at diagnosis was 61.5 (range 49-82). In our lot of patients, the big majority presented with squamous carcinoma (78\%) and $23 \%$ were adenocarcinoma according to biopsy. At the diagnosis 22 patients $(16.6 \%)$ were stage IV and $50(37.9 \%)$ presented with good performance status ECOG 0, $63(47.7 \%)$ with ECOG 1 and $19(14.4 \%)$ with ECOG 2. Patients characteristics are summarised in Table 1.

Regarding treatment modality, radiotherapy was administered in $83(62.9 \%)$ of patients. After conversion to surgery radiotherapy was administered as adjuvant treatment in 8\%. Mean dose of radiotherapy administered was 48.6Gy. Median duration of radiotherapy was

\section{Table 1.}

\begin{tabular}{lc}
\hline Characteristics & Number of patients (\%) \\
\hline Number of patients & $132(100 \%)$ \\
\hline Median age (years) & 60.6 (range 33-82) \\
\hline Gender & \\
Feminin & $29(22 \%)$ \\
Masculin & $103(78 \%)$ \\
\hline Stage & \\
Stage III & $110(83.3 .3 \%)$ \\
Stage IV & $22(16.6 \%)$ \\
Histological type & \\
Squamous & $53(77.7 \%)$ \\
Adenocarcinoma & $13(22.3 \%)$ \\
\hline ECOG & \\
ECOG 0 & $50(37.9 \%)$ \\
ECOG 1 & $63(47.7 \%)$ \\
ECOG 2 & $19(14.4 \%)$ \\
\hline
\end{tabular}




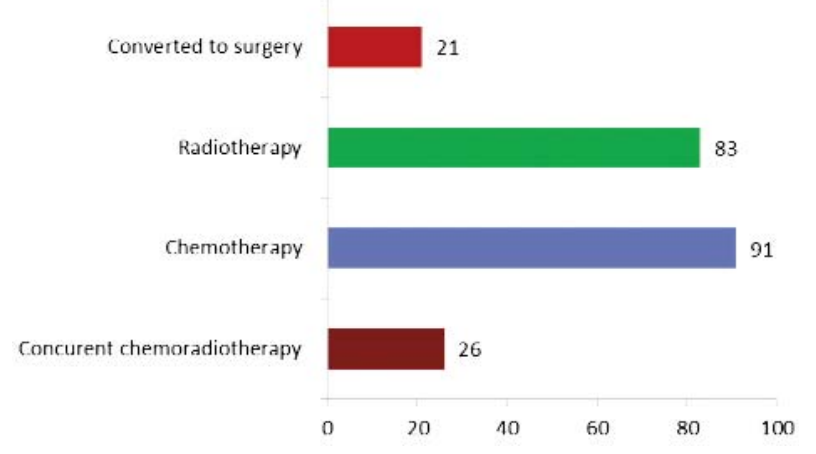

Figure 1. Treatment modality

41 days. Concurrent chemo-radiotherapy was administered in 26 (19.7\%). Chemotherapy was administered in 91 patients $(68.9 \%)$. The most used regimen was 5-FU and Cisplatin in 68.1\% of the patients who underwent chemotherapy. (Fig. 1). After multimodality treatment 21 (15.9\%) inoperable at diagnostic patients were converted to surgery. Surgery consisted in subtotal or total esophagectomy or gastrostomy.

Eighty four percent of patients in metastatic setting received second line chemotherapy.

After a median follow up of 17.3 months median overall survival (OS) for the population was 12 months, with one-year survival rate of $49.2 \%$ and 2 -year survival rates of $17.4 \%$. (Fig. 2)

In metastatic patients median overall

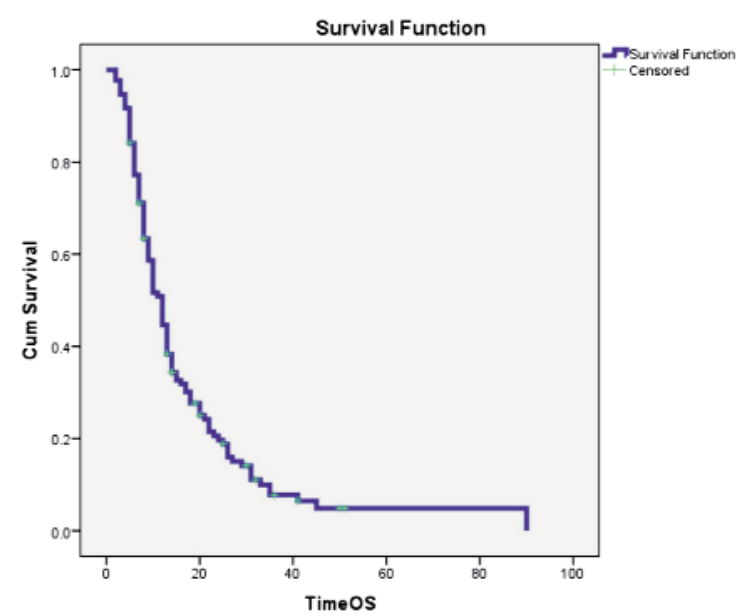

Figure 2. Overall survival in all patients

survival was 10 months and one year survival rate of $45.45 \%$ and 2 year survival rate of $13.63 \%$. For stage III median overall survival rate was 12 months and one year survival rate of $50 \%$ and 2 year survival rate of $18.2 \%$. (Fig. 3)

In locally advanced patients there was a clear advantage for three modality treatments. Patients who were converted to operability had a median estimated OS of 20 months compare to 10 months in patients who did not undergo surgery ( $\mathrm{p}=0.002)$ (Log Rank) (Fig. 4 A).

Chemo-radiotherapy was superior in terms of overall survival compare with chemotherapy
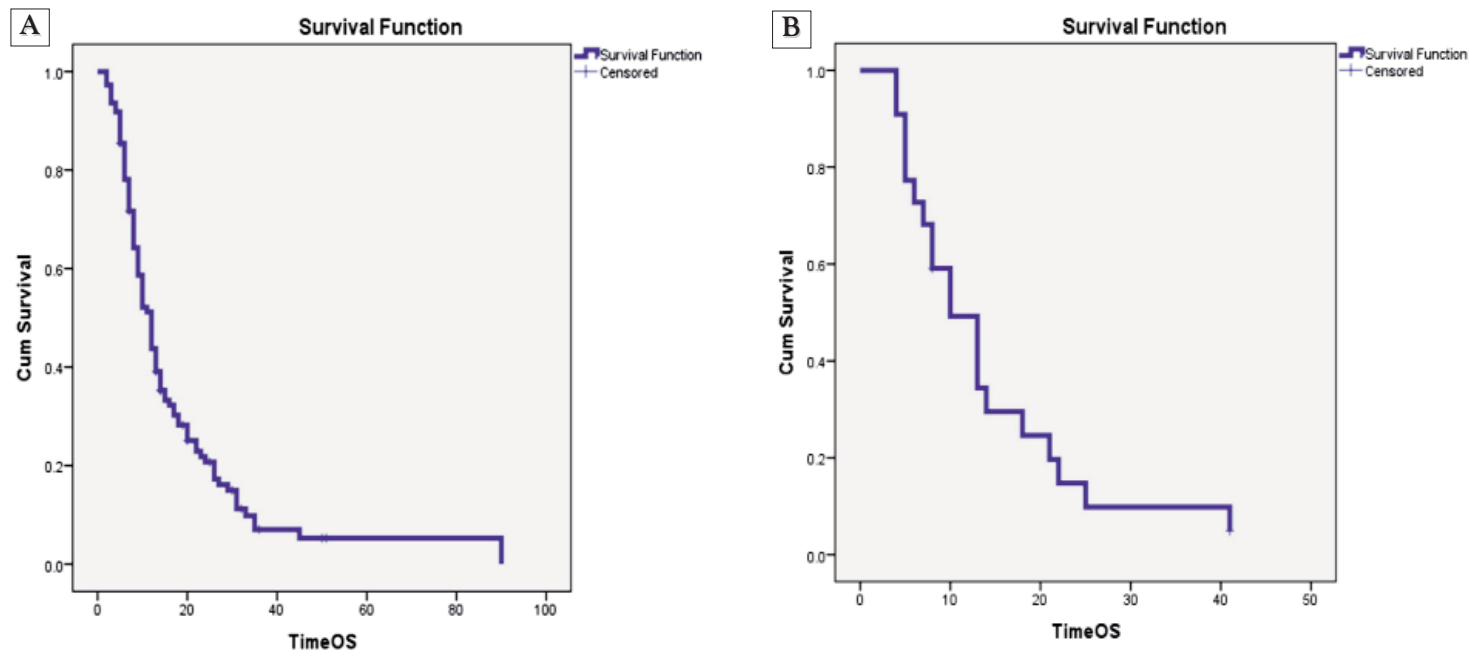

Figure 3. Median overall survival in stage IV (A) and III (B) 

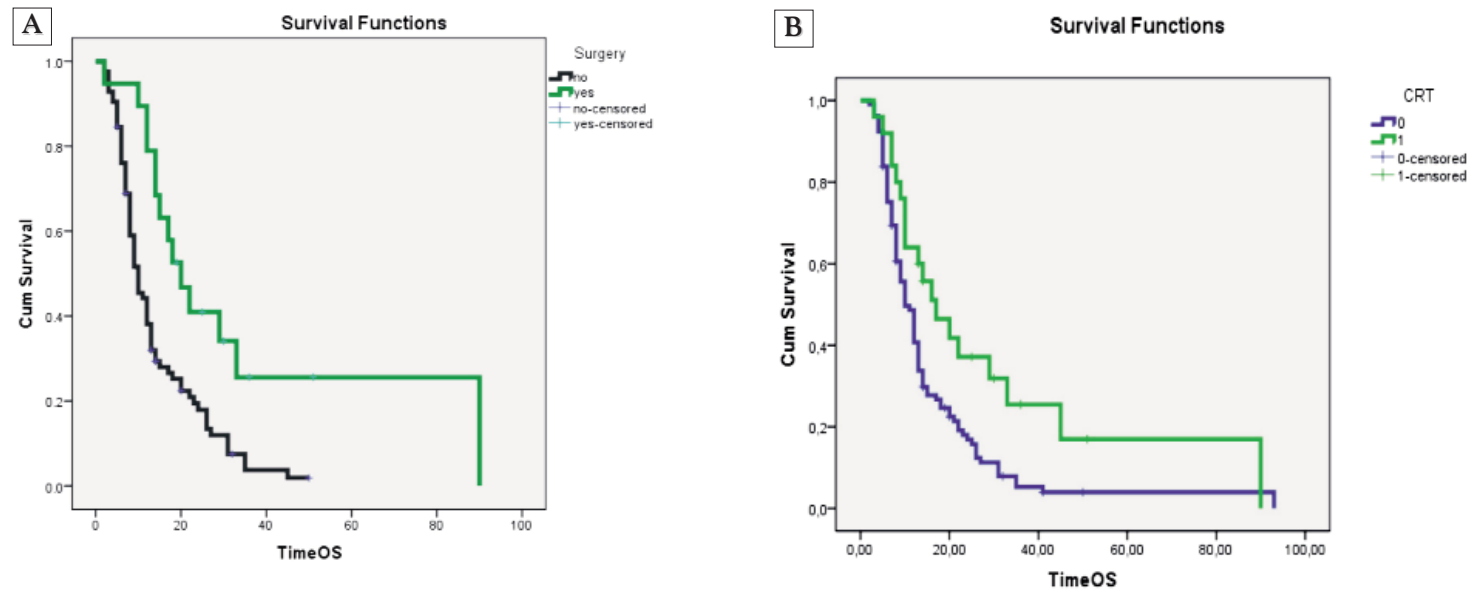

Figure 4. Median overall survival according to treatment (A) Benefit for adding surgery; (B) Benefit of chemoradiotherapy compare to radiotherapy alone

or radiotherapy administered sequential (17 months vs. 10 months), $\mathrm{p}=0.013$ (Log Rank). The rate of haematological toxicity (all grades according to CTCAE4) during chemo-radiotherapy was $38.4 \%$ but only $3(11.5 \%)$ were severe (grade 3 and 4) (Fig. 4 B).

In our group of patients there was no significant difference regarding OS between genders, histological type, chemotherapy vs. radiotherapy as the first treatment choice. (Fig. 5).

$\mathbf{A}$

Survival Functions

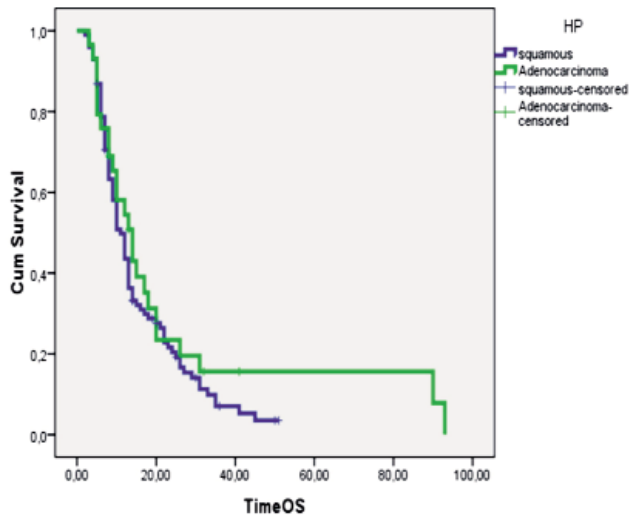

Discussions

There is no consensus regarding the treatment of patients with locally advanced and metastatic esophageal cancer and the best modality is that the treatment strategy has to be individualised and the case discussed in a tumour-board including a surgent, radiotherapist and oncologist.

In an attempt to improve the outcome of patients, considering that the relapse is

Survival Functions

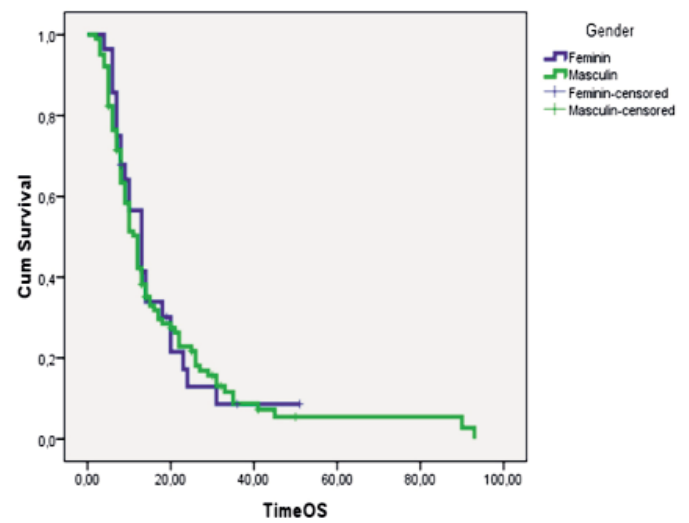

Figure 5. No significant difference between gender, histological type 
frequently locally and distant, chemo-radiotherapy was tested in patients with locally advanced oesophageal cancer. RTOG 85-01 study (6) Herskovic included patients with squamous cell carcinoma and esophageal adenocarcinoma who were expected to receive 4 cycles of chemotherapy consisting of 5-Fluorouracil and cisplatin, concurrently with external beam radiotherapy to a total dose of 50 Gy. The control arm of the study consisted only in radiotherapy at a higher dose than in concomitant chemoradiotherapy (64 Gy). Patients who were randomized to concomitant chemoradiotherapy had an improvement in median survival (14 months vs. 9 months) and survival at 5 years $(27 \%$ vs. $0 \%)$. Also, the incidence of local relapses (defined as lesion persistence or recurrence) was lower in the arm of patients receiving chemoradiotherapy (47\% vs. $65 \%$ ). However, chemoradiotherapy was associated with a higher rate of toxicity (Grade 3: $44 \%$ vs. $25 \%$, Grade 4: $20 \%$ vs. $3 \%$, Grade 5: $2 \%$ vs. $0 \%$ ). (7) Escalation of the radiotherapy dose received concurrently with chemotherapy from 50.4 Gy to 64.8 Gy was tested in INT 0123 study but unfortunately there was no statistically significant differences in median survival (13 vs. 18.1 months) or 2 years (31\% vs. $40 \%$ ) between higher radiation doses and those who received the dose standard (8). In our lot, the patients receiving concurrent chemoradiotherapy had a significantly better overall survival compared to radiotherapy and compared to chemotherapy alone, emphasising the importance of multidisciplinary team in fit patients suitable for aggressive treatment. Unfortunately, radio-chemotherapy could be administered only in 26 patients $(19.7 \%)$.

Nowadays it was attempted to incorporate in the chemoradiotherapy regimes the new compounds that proved to be effective. Thus, chemoradiotherapy with docetaxel $\left(60 \mathrm{mg} / \mathrm{m}^{2}\right)$ and cisplatin $\left(80 \mathrm{mg} / \mathrm{m}^{2}\right)$ administered at 3 weeks in combination with external radiotherapy was tested in 59 patients with esophageal squamous cell carcinoma and associated with a response rate of $98 \%$ and a $71 \%$ complete response rate, which resulted in a median survival of 23 months (9). Li
Paclitaxel and carboplatin administered in a weekly manner is another option with a better toxicity profile. In our lot of patients this treatment proved to be efficacious and well tolerated.

The best treatment strategy for the nonmetastatic disease patients was to be converted to surgery. In our study 21 of $110(19,1 \%)$ non- $^{-}$ metastatic patients converted to surgery. In this subset of patients, median overall survival was 39 months vs. 15 month with chemo and radiotherapy. The decision and the difficulty of surgery after chemoradiotherapy is well known but the benefit of trimodally treatment is clear (10). Several meta-analyses have attempted to determine the exact benefit of radio-chemotherapy followed by surgical intervention as opposed to surgery alone. Most of the studies tested the combination of cisplatin $75 \mathrm{mg} / \mathrm{m}^{2}$ and 5-Fluorouracil 1000 $\mathrm{mg} / \mathrm{m}^{2}$ day $1-4$ or $1-5$ associated with external radiotherapy (30-60 Gy) and followed 4-8 weeks after surgery. The complete pathologic response rate was between 15 and $25 \%,(\mathrm{OR}=$ 0.53) for the combination of chemoradiotherapy and surgery, higher for patients with squamous cell carcinoma and for those receiving higher doses of radiotherapy; the rate of local and distant recurrence was lower for triple therapy $(\mathrm{OR}=0.66$ for local relapses and $\mathrm{OR}=$ 0.44 for distant metastases) Postoperative mortality rate was less than $10 \%$ higher for combination therapy (OR $=1.63)(11)$. Survival data show a benefit of approximately $10 \%$ in favor of concomitant chemoradiotherapy followed by surgical intervention as a single therapeutic approach (the 3-year mortality rate favoured triple treatment $\mathrm{OR}=0.53$ $\mathrm{p}=0.03)$ (12). Also, a meta-analysis involving 1209 resected patients with esophageal adenocarcinoma and squamous cell carcinoma treated with chemoradiotherapy and 1724 surgical patients showed statistically significant survival benefit (OR $=0.81, p=0.002)$, which corresponds to an absolute survival difference of $13 \%$ at 2 years (13). In 2009, Stahl publish a study that tested neoadjuvant chemotherapy followed by surgery vs. neoadjuvant chemotherapy followed by radio-chemotherapy, 
followed by surgery and showed a statistically significant increase in overall survival at 3 years $(27.7 \%$ vs. $47.7 \%, \mathrm{p}=0.07)(14)$.

A more recently analysis showed that in a group of 85 patients treated with concurrent chemo-radiotherapy, 32 were pathologically responders and 48 underwent resection. The conclusion of the study was that chemoradiotherapy increase resectability, improves survival and does not affect postoperative complications and postoperative mortality, (15). Much effort should be made in order to identify the patients who will benefit the most from neoadjuvant chemotherapy (16).

The possibility to incorporate all this trials into clinical practice is limited by the fact that our patients especially those with squamous histology presented in very advanced stage and had a lot of comorbidities which reflects the big number of patients with ECOG 1 and 2 and the possibility to administered toxic concurrent treatment to a small amount of patients.

\section{Conclusion}

In conclusion, concurrent radio-chemotherapy followed by surgery can be considered superior to each method as single therapy and radiotherapy and chemotherapy can make certain locally advanced esophageal tumors resectable. Multimodality treatment gives the best chance of overall survival. For metastatic patients, multiples lines of chemotherapy are feasible and provides the best outcome.

\section{References}

1. Globocan larc $2012 \mathrm{http}: / /$ globocan.iarc.fr

2. Napier KJ, Scheerer M, Misra S. Esophageal cancer: A Review of epidemiology, pathogenesis, staging workup and treatment modalities. World J Gastrointest Oncol. 2014;6(5):112-20. doi: 10.4251/wjgo.v6.i5.112.

3. Oesophageal Cancer: ESMO Clinical Practice Guidelines

4. Pennathur A, Gibson MK, Jobe BA, Luketich JD. Oesophageal carcinoma. Lancet. 2013;381(9864):400-12. doi: 10.1016/S01406736(12)60643-6.

5. Shaheen 0, Ghibour A, Alsaid B. Esophageal Cancer Metastases to Unexpected Sites: A Systematic Review. Gastroenterol Res Pract. 2017;2017:1657310. doi: 10.1155/2017/1657310. Epub 2017 Jun 4.

6. Herskovic A, Martz K, al-Sarraf M, Leichman L, Brindle J, Vaitkevicius $\mathrm{V}$, et al. Combined chemotherapy and radiotherapy compared with radiotherapy alone in patients with cancer of the esophagus. N Engl J Med. 1992;326(24):1593-8.

7. Cooper JS, Guo MD, Herskovic A, Macdonald JS, Martenson JA Jr, Al-Sarraf M, et al. Chemoradiotherapy of locally advanced esophageal cancer: long-term follow-up of a prospective randomized trial (RTOG 85-01). Radiation Therapy Oncology Group. JAMA. 1999;281(17): 1623-7.

8. Minsky BD, Pajak TF, Ginsberg RJ, Pisansky TM, Martenson J, Komaki R, et al. INT 0123 (Radiation Therapy Oncology Group 9405) phase III trial of combined-modality therapy for esophageal cancer: high-dose versus standard-dose radiation therapy. J Clin Oncol. 2002;20(5): 1167-74.

9. Li QQ, Liu MZ, Hu YH, Liu H, He ZY, Lin HX. Definitive concomitant chemoradiotherapy with docetaxel and cisplatin in squamous esophageal carcinoma. Dis Esophagus. 2010;23(3):253-9. doi: 10.1111/j.1442-2050.2009.01003.x. Epub 2009 Aug 28.

10. Hanna A, Birla R, losif C, Boeriu M, Tomsa R, Puscasu A, et al. Evaluation of Neoadjuvant Radiochemotherapy Response (RCT) in Squamous Esophageal Cancer (ESC) and Implications in Therapeutic Conduct. Chirurgia (Bucur). 2015;110(3):214-23.

11. Urschel JD, Vasan H. A meta-analysis of randomized controlled trials that compared neoadjuvant chemoradiation and surgery to surgery alone for resectable esophageal cancer. Am J Surg. 2003; 185(6):538-43.

12. Fiorica F, Di Bona D, Schepis F, Licata A, Shahied L, Venturi A, et al. Preoperative chemoradiotherapy for oesophageal cancer: a systematic review and meta-analysis. Gut. 2004;53(7):925-30.

13. Gebski V, Burmeister B, Smithers BM, Foo K, Zalcberg J, Simes J, et al. Survival benefits from neoadjuvant chemoradiotherapy or chemotherapy in oesophageal carcinoma: a meta-analysis. Lancet Oncol. 2007;8(3):226-34.

14. Stahl M, Walz MK, Stuschke M, Lehmann N, Meyer HJ, RieraKnorrenschild J, et al. Phase III comparison of preoperative chemotherapy compared with chemoradiotherapy in patients with locally advanced adenocarcinoma of the esophagogastric junction. J Clin Oncol. 2009;27(6):851-6. doi: 10.1200/JC0.2008.17.0506. Epub 2009 Jan 12.

15. Hanna A, Birla R, Iosif C, Boeriu M, Constantinoiu S. Benefits and Disadvantages of Neoadjuvant Radiochemotherapy (RCT) in the Multimodal Therapy of Squamous Esophageal Cancer (ESC). Chirurgia (Bucur). 2016;111(1):12-25.

16. Predescu D, Gheorghe M, Boeriu M, Constantin A, Iosif C, Anghel $\mathrm{R}$, et al. Molecular factors and criteria for predicting the response to neoadjuvant treatment in patients with esophageal squamous cell carcinoma (ESCC) -- responder/non-responder. Chirurgia (Bucur). 2012;107(5):583-90. 